\title{
Produkcja wydawnicza i drukarska na rzecz oświaty w świetle bibliografii „Druki kaliskie XIX i pierwszej połowy XX w."
}

\section{Bibliografia druków kaliskich, jej metoda i zawartość}

\section{Tradycje bibliografii druków kaliskich}

Pierwsze informacje o drukach kaliskich pojawiły się w wieku XVIII w pracy Jana Daniela Hoffmanna w 1740 r. oraz w drukowanych katalogach kaliskich oficyn $(1765,1779)$, kolejne przyniósł wiek XIX w pracach Jerzego Samuela Bandtkiego (1826), Joachima Lelewela (1823-1826) i Cezarego Biernackiego (1857, 1859). Uwagę zwraca jednak rękopis Antoniego Pstrokońskiego z 1831 r. pt. Druki kaliskie. Zacząwszy od naydawniejszego spisane r. 1831 w sierpniu zawierający spis ponad 200 druków kaliskich.

Dopiero w roku 1887 w toku dyskusji nad kalendarzami kaliskimi na łamach „Kaliszanina” wyłonił się projekt sporządzenia kompletnej bibliografii druków kaliskich. I choć zamiar opracowania bibliografii wyrażał C. Biernacki, to udało mu się tylko sporządzić katalog XVII-wiecznych druków, który przesłał Karolowi Estreicherowi do Bibliografii polskiej, brak jednak informacji o spisie druków z wieku XVIII i XIX.

W okresie międzywojennym prace nad bibliografią podjęło Towarzystwo Przyjaciół Książki w Kaliszu (1927-1936), stawiając sobie jako jeden z celów sporządzenie pełnej bibliografii druków kaliskich. Pomóc w tym miała zorganizowana

* Dr hab., prof. UŁ, Uniwersytet Łódzki, Wydział Filologiczny, Katedra Bibliotekoznawstwa i Informacji Naukowej, 90-237 Łódź, ul. Jana Matejki 34a. 
w 1928 r. wystawa pod nazwą „325 lat drukarstwa kaliskiego” i wydanie katalogu, który stał się pierwszą bibliografią podmiotową druków kaliskich. Autorem katalogu był Stefan Dybowski, który kontynuował prace bibliograficzne, ogłaszając na łamach „Ziemi Kaliskiej” bieżącą bibliografię podmiotową i przedmiotową. Niestety systematyczne publikowanie bibliografii zakończyło się po dwóch numerach, choć Dybowski prac nie przerwał. Zebrane przez niego materiały uległy jednak zniszczeniu w czasie II wojny światowej.

Podjęte po wojnie przez Władysława Kwiatkowskiego i S. Dybowskiego prace bibliograficzne nie zostały zrealizowane. Dopiero w roku 1980 ukazała się pełna bibliografia starych druków kaliskich w opracowaniu Krystyny Bielskiej, rok 1994 z kolei przyniósł spis edycji kaliskich kalendarzy, a na jubileusz czterechsetlecia drukarstwa kaliskiego w 2003 r. ukazała się bibliografia dokumentująca produkcję miejscowych zakładów drukarskich w XIX i pierwszej połowie XX w. Dwa lata później (2005) na jubileusz 200-lecia prasy kaliskiej przygotowany został spis miejscowych periodyków w postaci Bibliografii prasy kaliskiej 1805-20051.

\section{2. „Druki kaliskie XIX i pierwszej połowy XX w.” - charakterystyka bibliografii}

Bibliografię „Druki kaliskie XIX i pierwszej połowy XX w.”, dokumentującą w układzie chronologicznym produkcję miejscowych tłoczni od roku 1800 do 1945, opracowali kaliscy bibliotekarze: Ewa Andrysiak, Krzysztof Walczak i Danuta Wańka². Spis - oparty na autopsji i opisach bibliograficznych przejętych ze źródeł - stanowi pierwszą próbę pokazania dorobku miejscowych drukarni na przestrzeni ponad 140 lat. Odnotowuje zarówno tytuły wydawnictw zwartych, jak i wszelkich periodyków, mapy, a także dokumenty życia społecznego (obwieszczenia, ogłoszenia, afisze, programy teatralne i in.), choć jeśli chodzi o kompletność dżs-ów, to zapewne udało się to w niewielkim stopniu. Do opracowania spisu wykorzystano bibliografie (ogólne - Bibliografia polska K. Estreichera, Bibliografia polska 1901-1939 i specjalne), katalogi księgarskie, antykwaryczne i aukcyjne, także katalogi bibliotek kaliskich i wybranych na terenie kraju, czasopisma bibliograficzne i prasę lokalną. Pracę, poza indeksami (osobowym, tytułowym i drukarni), uzupełniają sigla sześciu kaliskich bibliotek posiadających poszczególne egzemplarze miejscowych druków.

Dziś do bibliografii druków kaliskich XIX i I połowy XX w. można dopisać kolejnych kilkadziesiąt publikacji, a ukazujące się tomy Bibliografii polskiej 1901-1939 przyniosą z pewnością następne, nieznane dotąd tytuły.

1 Szerzej na temat bibliografii druków kaliskich zob. E. Andrysiak, Bibliografia Kalisza. Dzieje, stan prac i zamierzenia, [w:] Książka, biblioteka, informacja. Między podziałami a wspólnotą. II, red. J. Dzieniakowska, I. Krasińska, M. Olczak-Kardas, Kielce 2011, s. 149-164.

2 Kalisz, Kaliskie Towarzystwo Przyjaciół Nauk, 2003. 


\section{Kalisz jako ośrodek drukarski i wydawniczy}

\section{Tradycje drukarskie miasta}

Początki drukarstwa kaliskiego sięgają roku 1602, kiedy do Kalisza przybył Jan Wolrab zwany Młodszym, uruchamiając tu, za namową jezuitów, tłocznię na potrzeby miejscowego Kolegium Jezuickiego. Pierwszy druk - Katechizm rzymski - opuścił drukarnię w roku 1603. Od 1603 do 1793 r., czyli w okresie 190 lat, w grodzie nad Prosną działało kolejno pięć tłoczni: Jana Wolraba (1602-1604), Wojciecha Gedeliusza (1605-1632), Kolegium Jezuickiego (1633-1773) oraz Oficyna Jego Królewskiej Mości Rzeczypospolitej (1774-1781) i Oficyna J.O. X-cia Prymasa Arcybiskupa Gnieźnieńskiego (1782-1793).

Nowy okres w dziejach kaliskiego drukarstwa rozpoczął rok 1800, kiedy drukarnię uruchomił Karol Wilhelm Mehwald, założyciel drukarskiej dynastii Mehwaldów i Hindemithów, kontynuującej drukarskie tradycje miasta do roku 1914: K. W. Mehwald (1800-1824), Joanna Zuzanna Mehwald (1824-1835), Karol Wilhelm Hindemith (1835-ok. 1884), Oswald Arno Hindemith (ok. 1884-1914).

Od roku 1825 pojawiały się w mieście kolejne oficyny i zakłady litograficzne, m.in. litografia T. J. Jaenischa (1825-1841), drukarnia Wojciecha Koszewskiego i Piotra Karśnickiego (1830-1844), drukarnia i litografia Maurycego Schindele (1836-1845), drukarnia Adama Czerwińskiego (1883-1914), zakład drukarsko-litograficzny Bronisława Szczepankiewicza (1880-1895), drukarnia „Gazety Kaliskiej" (Józefa Radwana, 1899-1914).

Przerwę w działalności zakładów drukarskich spowodowało zniszczenie Kalisza w sierpniu 1914 r., ponowny rozwój przyniósł okres dwudziestolecia międzywojennego. Obok nielicznych firm drukarskich kontynuujących działalność rozpoczętą przed 1914 r., powstało wiele nowych. Działała drukarnia "Gazety Kaliskiej” (Radwanów, 1916-1939), Drukarnia Pospieszna Jakuba Szczecińskiego (1917-1939), Drukarnia Ziemi Kaliskiej - Chrześcijańska Drukarnia Ziemi Kaliskiej (Antoniego Krawczyka, 1921-1939), Drukarnia Wydawnicza Wolfów (1927-1935), drukarnia „Echo Kaliskie llustrowane” Józefa Pietrzyckiego (1933-1939) i in.

2. Instytucje wydawnicze aktywne na terenie miasta

Dzieje miejscowego ruchu wydawniczego rozpoczyna rok 1602, rok przybycia do Kalisza pierwszego drukarza, tłoczącego druki na zamówienia jezuitów, którzy do kasaty zakonu w roku 1772 prowadzili działalność wydawniczą.

Nowy rozdział w dziejach ruchu wydawniczego zapoczątkował wiek XIX. Działalność wydawniczą podjął drukarz K. W. Mehwald, a kontynuowali ją 
jego następcy - żona Joanna Zuzanna Mehwald, Karol Wilhelm. Hindemith i Oswald Arno Hindemith, którzy mieli swój udział w wydawaniu kaliskich czasopism i kalendarzy. Własnym nakładem "nowe kalendarze domowe i gospodarskie" tłoczyła drukarnia Maurycego (Moritza) Schindele (od 1836). Nie można pominąć oczywiście drukarni Józefa Radwana, wydającego własnym nakładem "Gazetę Kaliską", która na początku wieku XX zdominowała miejscowy rynek wydawniczy.

W ruch wydawniczy włączyły się również księgarnie. Edycje katalogów czytelni księgarnianych i nakłady druków muzycznych tłoczyły firmy Henryka i Alfonsa Hurtigów oraz Juliusza Mitwocha. Działalność edytorską prowadziła księgarnia Jana i Michała Grabowskich, później Katarzyny Grabowskiej. Edycje utworów muzycznych w oparciu o własny zakład litograficzny publikował Edward Rühl, właściciel „Nowej Księgarni”, a działająca w latach 1895-1914 drukarnia Jakuba Kohna była m.in. wydawcą „Kuriera Kaliskiego”. Działania edytorskie prowadziła zasłużona dla miasta księgarnia Bronisława Szczepankiewicza (1876-1912). Instytucją wydawniczą Kalisza był urząd gubernatora kaliskiego, na zlecenie którego tłoczone były m.in. druki urzędowe. Poza tym szereg instytucji i stowarzyszeń wydawało roczne sprawozdania z działalności ${ }^{3}$.

Zniszczenie miasta w sierpniu 1914 r. na kilka lat przerwało działalność większości instytucji i przedsiębiorstw, w tym księgarni i drukarni. W zmienionych warunkach nie wszystkie firmy podjęły działalność, powstało jednak wiele nowych, w tym także związanych z książką. Podobnie jak w okresie wcześniejszym, działalność wydawniczą podejmowały drukarnie i księgarnie. Nadal inicjatywy wydawnicze kontynuowała drukarnia "Gazety Kaliskiej” Radwanów. W latach 1927-1935 działalność wydawniczą prowadziła Drukarnia Wydawnicza. Kaliskie drukarnie tłoczyły też dla wydawców Iwowskich, warszawskich i poznańskich. Pośród działających w okresie międzywojennym księgarni w ruchu wydawniczym widoczna była księgarnia Maksymiliana Jasińskiego działająca w latach 1918-1939, jej nakładem ukazały się m.in. prace dotyczące języka esperanto.

Szereg wydawnictw wydał Magistrat miasta Kalisza. Pominąć nie sposób edycji Kaliskiego Oddziału Polskiego Towarzystwa Krajoznawczego oraz działającego w latach 1927-1936 Towarzystwa Przyjaciół Książki w Kaliszu.

Podobnie jak w okresie wcześniejszym, wiele instytucji, organizacji i stowarzyszeń wydawało sprawozdania z działalności (Towarzystwo Wioślarskie, Kaliska Ochotnicza Straż Pożarna, Ubezpieczalnia Społeczna, Towarzystwo Kredytowe $\mathrm{m}$. Kalisza). Działalność wydawniczą podejmowały organizacje szkolne i harcerskie, zakonnicy (franciszkanie) i księża (ks. Jerzy Bekier).

${ }^{3}$ Zob. szerzej: K. Walczak, Na pograniczu kultur. Ruch wydawniczy w dziewiętnastowiecznym Kaliszu, [w:] Książka, biblioteka, informacja..., s. 21-29. 


\section{Produkcja wydawnicza i drukarska - charakterystyka zbioru}

\section{Oświatowe akty prawne}

Zaledwie kilka druków zaliczyć można do grupy oświatowych aktów prawnych, wszystkie pochodzą z pierwszej dekady wieku XX, w tym dwa są związane ze szkolnictwem handlowym. Na początku XX w. grupa 165 mieszkańców Kalisza i ówczesnej guberni kaliskiej wystąpiła z inicjatywą utworzenia szkoły średniej. Opracowaną ustawę placówki wydał w roku 1904 Józef Radwan, właściciel drukarni „Gazety Kaliskiej” i jeden z założycieli szkoły. Ustawa Szkoły Handlowej siedmioklasowej w Kaliszu ${ }^{4}$ ukazała się w dwujęzycznej wersji polsko-rosyjskiej (strony parzyste - tekst rosyjski, nieparzyste - polski). Szkoła Handlowa rozpoczęła działalność w styczniu 1906 r., w tymże roku z drukarni K. W. Hindemitha wyszła Ustawa Towarzystwa Pomocy dla niezamożnych uczniów 7-mio klasowej Szkoły Handlowej w Kaliszu ${ }^{5}$.

Rok 1908 przyniósł Ustawę Kaliskiego Towarzystwa Oświatowego. Około 1908 r. ukazała się Ustawa Towarzystwa Biblioteki i Czytelni publicznej im. Adama Mickiewicza w Kaliszu ${ }^{6}$, tłoczona w Drukarni „Gazety Kaliskiej”, ustawa biblioteki działającej początkowo (1907) jako sekcja kaliskiego koła Polskiej Macierzy Szkolnej i mającej charakter placówki oświatowej.

\section{Szkolnictwo i jego instytucje (prace teoretyczne, szkoły różnych typów)}

W latach 1808-1939 ukazało się kilkanaście druków poświęconych dziejom kaliskiego szkolnictwa. Około roku 1808 Karol Herzberg (Hertzberg 1769-1812) ${ }^{7}$ opublikował krótki czterostronicowy opis zakładu pt. Instytut edukacyjny Herzberga konsyliarza konsystors.[kiego] superinten.[denta] $i$ prof. w Kaliszu. Druk zapewne, jak i dwa inne tego autora, tłoczył Karol Wilhelm Mehwald. W 1795 r. Herzberg został pastorem utworzonej w Kaliszu parafii ewangelicko-augsburskiej, był radcą Konsystorza. Od roku szkolnego 1802-1803 pracował jako nauczyciel w Szkole Akademickiej Okręgowej (od 1807 Królewskie Gimnazjum Kaliskie), zatrudniony przez władze pruskie, uczył historii powszechnej, języka greckiego i rysunków; w szkole pracował do śmierci.

W kręgu zainteresowań nauczyciela i regionalisty Władysława Kwiatkowskiego znalazł się Teatr szkolny kollegium jezuickiego w Kaliszu. Publikacja, wydana

${ }^{4}$ Ustav' kališskago semiklassnago komerčeskago učilišča [Ustawa Szkoły Handlowej siedmioklasowej w Kaliszu], Kalisz, 1904, [Druk.] Gazety Kaliskiej.

5 Kalisz, 1906, druk K. W. Hindemita.

6 Kalisz, [ok. 1908], Drukarnia „Gazety Kaliskiej”.

7 K. Walczak, Herzberg (Hertzberg) Karol Fryderyk Wedding, [w:] Słownik biograficzny Wielkopolski południowo-wschodniej-ziemi kaliskiej, t. 2, red. D. Wańko, Kalisz 2003, s. 85. 
przez kaliski Oddział Polskiego Towarzystwa Krajoznawczego, wyszła w serii „Biblioteka Kaliska”. O miejscowych szkołach w latach 1793-1806 pisał Kazimierz Stefański w broszurze pt. Szkoły kaliskie za czasów pruskich (1793-1806)99. O Korpusie Kadetów, jego utworzeniu i wprowadzonych zmianach pisał w 1816 r. profesor tej szkoły Józef Frankowski. W wydawnictwie pt. O założeniu Szkoły Rycerskiéy Kaliskiéy, a odmianach dotąd w niéy zaszłych, kilka słów, ... ${ }^{10}$ znalazł się też wiersz autorstwa J. Fritschego, czytany przy zawieszeniu portretu Stan. hr. Potockiego w sali popisowej, oraz plan nauk.

Kilka druków to prace dotyczące dzisiejszego I LO im. A. Asnyka, szkoły której nazwy zmieniały się kilkunastokrotnie. W roku 1874 jako odbitka z „Kališskich Gubernskich Vedmostej” opublikowana została Kratkaja istoričeskaja zapiska o kališskoj Mužskoj Gimnazii W. Sawickiego. Z drukarni Adama Czerwińskiego w roku 1900 wyszła praca Ambrożego Idzikowskiego pt. Szkoła Kaliska [Szkoła Wyższa Realna - Gimnazyum], obejmująca lata 1850-190011. W wydawnictwie znalazły się także wiersze Adama Asnyka i Stefana Gillera - nauczyciela szkoły.

W roku 1933 z kolei ukazał się Zarys historii Państwowego Gimnazjum im. Adama Asnyka w Kaliszu autorstwa Ludomira Fabrycego, wydany nakładem Komitetu Rodzicielskiego tegoż gimnazjum ${ }^{12}$. Na prawach rękopisu drukarnia Józefa i Antoniego Radwanów tłoczyła Katalog biblioteki uczniowskiej I Państw [owego] Gimnazjum i Liceum im. Adama Asnyka w Kaliszu (1938) ${ }^{13}$.

W styczniu 1906 uruchomiono w Kaliszu 7-klasową Szkołę Handlową, w lipcu tego roku w „Kaliszaninie” opublikowano sprawozdanie z jej działalności; drukiem ukazało się także sprawozdanie za rok szkolny 1910-19114.

Dwa druki w kaliskiej produkcji wydawniczej i drukarskiej XIX i pierwszej połowy XX w. na rzecz oświaty to przyczynki biograficzne. Życiorys księdza Ignacego Przybylskiego, w latach 1818-1824 rektora Szkoły Departamentowej (od 1819 Szkoły Wojewódzkiej) Kaliskiej, opracowany przez kaliskiego historyka Adama Chodyńskiego ${ }^{15}$ i opublikowany w „Noworoczniku Kaliskim na rok 1876” ukazał się w tym samym roku także w osobnej odbitce. Przemówienie wygłoszone 13 czerw-

8 Kalisz, Kaliski Oddz. Polskiego Tow. Krajozn., 1936 (Biblioteka Kaliska; nr 4).

9 Kalisz, [b.w.], 1923 (Druk. Ziemi Kaliskiej).

10 J. Frankowski, O założeniu Szkoły Rycerskiéy Kaliskiéy, a odmianach dotąd w niéy zaszłych, kilka słów, przez które zapowiada się rozpoczęcie kursu lekcyy na rok 1816/17, w Szkole téy będącéy pod kommendą wielmożnego Regulskiego, Pułkownika, różnych Orderów Kawalera. Następnie Wiersz, czytany przy wystawieniu w sali Popisów obrazu Jwgo Hrabi Potockiego, senatora woiewody, ministra oświecenia publicznego i wyznań religiynych, kommendanta jederalnego kadetów, wielkich rożnych orderów kawalera etc. etc. Dołączone jest Wyszczególnienie Nauk dawnych Kadetom w roku 1815/16, Kalisz 1816.

11 A. Idzikowski, Szkoła Kaliska [Szkoła Wyższa Realna - Gimnazyum] 1850-1900, zebrał A. Idz..., Kalisz, druk. A. Czerwińskiego, 1900.

12 Kalisz, nakł. Komitetu Rodzicielskiego Gimnazjum im. A. Asnyka w Kaliszu, 1933 (Kalisz, Drukarnia Wydawnicza).

13 Kalisz, [b.w.], 1938 (Kalisz, druk J. i A. Radwanów).

14 Sprawozdanie Siedmioklasowej Szkoły Handlowej w Kaliszu za rok szkolny 1910-11, [Kalisz 1911] (Drukiem „Gazety Kaliskiej”).

15 A. Chodyński, Ks. Ignacy Przybylski rektor szkół poznańskich, płockich i kaliskich. Życiorys, Kalisz, 1876. 
ca 1926 r. na uroczystości poświęconej 40-leciu pracy społeczno-pedagogicznej F. Łączkowskiej uczennice wydały w broszurze pt. Ku czci Felicji Łączkowskiej 1886-1926 - uczennice ${ }^{16}$.

W dziesiątą rocznicę odzyskania niepodległości, nakładem Magistratu miasta Kalisza, wydano Dziesięciolecie szkolnictwa powszechnego w Kaliszu autorstwa Tadeusza Skrętnego ${ }^{17}$. Druk wyszedł w nakładzie 500 egzemplarzy na papierze ilustracyjnym i 30 egz. imiennych na papierze chromowanym. W roku 1928 wyszło też Sprawozdanie roczne z działalności Stowarzyszeń Młodzieży Polskiej w Kaliszu za rok 1928. Wymieniony już W. Kwiatkowski dopominał się O uwzględnienie dziejów Kalisza w nauczaniu historii Polski, tekst wydało Towarzystwo Przyjaciół Książki w Kaliszu w 1931 r., najpierw ukazał się na łamach „Ziemi Kaliskiej”, następnie w osobnej odbitce ${ }^{18}$.

W grupie druków dotyczących szkolnictwa odnotować należy druki wydane nakładem własnym autorów, czyli Wspomnienia kaliszanina o życiu młodzieży akademickiej w latach 1884-1888 Witolda Grabowskiego (1932) ${ }^{19}$ oraz Elementarny zarys nauki o Państwie i prawa administracyjnego dla użytku Szkół Policyjnych Jerzego Dołęgi-Kowalewskiego ${ }^{20}$. Poza tym interesujące jest wydawnictwo związane ze zjazdem absolwentów w 1923 r. - Pamiętnik Zjazdu Wychowańców Szkół Kaliskich 8-9 wrzesień 1923 w opracowaniu Juliana Biernackiego ${ }^{21}$.

\section{Szkolnictwo wyższe}

W kaliskiej produkcji wydawniczej znaleźć można także przykłady druków związanych ze szkolnictwem wyższym. Tłoczyła je w okresie międzywojennym kaliska Drukarnia Wydawnicza. Nakładem Koła Studentów Inżynierii Leśnej Politechniki Lwowskiej w roku 1927 w nakładzie tysiąca egzemplarzy ukazała się praca Stanisława Hubickiego Zabudowanie potoków górskich. Cz. 1. Regulacja progowa na średnią wielką wodę 22 . Na łamach „Sylwana” Franciszek Krzysik pisał o wycieczce studentów Wydziału Leśnego Politechniki Lwowskiej do Rumunii. Spółdzielnia Leśników we Lwowie wydała tekst także jako osobną odbitkę w nakładzie 150 egzemplarzy (1928 r. $)^{23}$. Obszerny podręcznik Handel materiałami drzewnymi Cyryla Kochanowskiego ${ }^{24}$ dla słuchaczy Wydziału Rolniczo-Leśnego Politechniki ukazał się w 1929 r.

${ }^{16}$ Kalisz [1926].

17 Kalisz, nakładem Magistratu miasta Kalisza, 1928 (Kalisz, Drukarnia Wydawnicza).

18 Kalisz, Towarzystwo Przyjaciół Książki, 1931 (Kalisz, Drukarnia Wydawnicza). Odbitka z „Ziemi Kaliskiej" 1931, nr 4-12.

19 Kalisz, nakł. autora, 1932 (Kalisz, Druk. Ziemi Kaliskiej).

20 Kalisz, nakł. autora, 1924 [1923?], Drukarnia Ziemi Kaliskiej.

21 Kalisz [1924], Drukarnia „Ziemi Kaliskiej”.

22 Lwów, Politechnika, nakł. Koła Studentów Inżynierii Lasowej, 1927 (Kalisz, Drukarnia Wydawnicza).

${ }^{23}$ F. Krzysik, Wycieczka studentów oddziału lasowego Politechniki Lwowskiej do Rumunii, Lwów, Spółdzielnia Leśników we Lwowie, 1928 (Kalisz, Drukarnia Wydawnicza S-ka z ogr. odp.).

${ }^{24}$ Lwów [b. w.], 1929 (Drukarnia Wydawnicza w Kaliszu). 
Nakładem i drukiem kaliskiej Drukarni Wydawniczej w roku 1930 wyszedł podręcznik metodyczny Kazimierza Adamczewskiego pt. Zasady kodeksu postępowania karnego 25 .

\section{Doskonalenie zawodowe (poradnictwo zawodowe i kursy, samodoskonalenie)}

W okresie międzywojennym ukazało się kilka druków z zakresu doskonalenia zawodowego i samodoskonalenia. W roku 1924 Drukarnia Ziemi Kaliskiej tłoczyła dla wydawnictwa "Ligi Pracy” w Warszawie Poradnictwo zawodowe. Zadania i metody, pracę szwajcarskiego psychologa, pedagoga i lekarza Edouarda Claparède ${ }^{26}$.

Przykład wydawnictw dla Ligi Obrony Przeciwlotniczej i Przeciwgazowej stanowią prace Wacława Bartoszkiewicza i Mikołaja Dziedzickiego pt. Skrót wykładów z chemii gazów trujących dla Komitetu Wojewódzkiego LOPP w Łodzi (nakł. 400 egz. $)^{27}$ oraz Aleksandra Tomankiewicza Skrypta wykładowe z kursu komendantów opl. [obrony przeciwlotniczej] domów (bloków) dla kaliskiego Obwodu Powiatowego LOPP28.

Na prawach skryptu do użytku szkoły podoficerskiej 60 pułku piechoty wyszedł Podręcznik dla instruktora przy wyszkoleniu bojowym pojedynczego żołnierza (zespołu i sekcji) Franciszka Kurbiela, porucznika tegoż pułku29.

Pod koniec 1891 r. z inicjatywy Felicji Łączkowskiej powstały i funkcjonowały „piątki literackie”, spotkania kobiet z kręgu kaliskiej inteligencji, prowadzone w celu samodoskonalenia. W roku 1931 na łamach „Ziemi Kaliskiej” przypomniano działalność „piątków”. Tekst pt. Jubileusz Piątków Literackich drukowano także jako uzupełnioną ilustracjami odbitkę w nakładzie 200 egzemplarzy ${ }^{30}$.

\section{Zagadnienia wychowania}

Kwestie związane $\mathrm{z}$ wychowaniem prezentują tłoczone w kaliskich drukarniach prace Christiana Wilhelma Hufelanda, Konstancji z Małachowskich Biernackiej, Pauliny Rościszewskiej, Józefa Bronisława Szafnickiego i Eugenii Beznerówny.

W roku 1808 Karol Wilhelm Mehwald tłoczył Dobrą radę dla matek w ważnych punktach fizycznego wychowania dzieci w pierwszych leciech... ${ }^{31}$, pracę

25 Kalisz, Kom. Dom Książki Polskiej, 1930 (Kalisz, nakł. i druk Druk. Wydawnicza).

26 Tł. Maria Sokalowa, Warszawa 1924 (Kalisz, Druk. Ziemi Kaliskiej). Wydawnictwo „Ligi Pracy" [3].

27 [Łódź 1935] (Kalisz, Druk. J. i A. Radwanowie).

28 Kalisz, Drukarnia Polska [1938].

29 Ostrów-Poznański 1928 (Kalisz, Drukarnia Ziemi Kaliskiej).

30 Kalisz, Towarzystwo Przyjaciół Książki, 1931 (Kalisz, Drukarnia Wydawnicza).

31 [Kalisz], druk. K. W. Mehwalda [1808]. 
niemieckiego lekarza Christopha Wilhelma von Hufelanda (1762-1836), profesora uniwersytetów w Jenie i Berlinie, uważanego za jednego z największych autorytetów lekarskich swojej epoki. Przekładu na język polski dokonał praktykujący w Kaliszu medyk Jonas Meyer - członek towarzystwa uczonych we Frankfurcie nad Odrą.

W 1829 r. z drukarni J. Poleskiego wyszły dwa tomy Rozmów Pawlunia z Babunią o kilkuset nawijających się przedmiotach czyli skazowka sposobu rozkrzewienia w dzieciach zdolności, pojęcia i szlachetnych upodobań podane ku pożytkowi dzieci umiejących dobrze czytać Konstancji Biernackiej (1773-1839), które autorka wydała pod pseudonimem ${ }^{32}$. Rozmowy Pawlunia z Babunią... uznawane są za pierwowzór encyklopedii dziecięcej.

Nakładem „Nowej Księgarni” Edwarda Rühla w Kaliszu ukazało się Kilka słów do mojego syna Pauliny Rościszewskiej, wydawnictwo tłoczył Ernest Günther w Lesznie ${ }^{33}$.

W latach 1884-1906 stanowisko prefekta w gimnazjum kaliskim zajmował ks. Józef Bronisław Szafnicki (1855-1919)34, autor wydanej w 1908 publikacji pt. O wychowaniu dzieci, z podtytułem, czy raczej dedykacją: rodzicom iście chrześcijańskim poświęca ks. J. B. Szafnick ${ }^{35}$.

Wydawnictwo dotyczące oddziaływania Pana Tadeusza Adama Mickiewicza na wychowanie drukowała w roku 1936 Drukarnia Jakuba Szczecińskiego, chodzi tu o tekst Eugenii Beznerówny pt. Wychowawczy wpływ „Pana Tadeusza”36.

Chrześcijańska Drukarnia Ziemi Kaliskiej Antoniego Krawczyka tłoczyła w roku 1938 krótkie, zaledwie czterostronicowe Abecadło Młodej Polki. (Wskazówki życiowe), które nakładem własnym wydał Oddział Katolickiego Stowarzyszenia Kobiet w Liskowie $^{37}$.

\section{Szkolne druki zwarte (elementarze, podręczniki, samouczki)}

\section{Elementarze}

W latach 1800-1945 odnotowano siedem edycji elementarzy, w tym sześć dziewiętnastowiecznych. Najstarsza to edycja w języku łacińskim pt. Elementa puerilia cum piis orationibus ac doctrina Christiana, niewielkich rozmiarów druczek $(15 \times 10 \mathrm{~cm})$ liczący 64 strony tłoczył w roku 1820 Karol Wilhelm Mehwald.

32 Rozmowy Pawlunia z babunią... przez Autorkę «Zabawy Polki z Synami» K... z H... B...ą, 2 części, Kalisz, J. Poleski, 1829.

33 Kalisz, nakł. Nowej Księgarni Edwarda Rühl, 1857 (Leszno, drukiem Ernesta Günthera).

34 D. Wańka, Szafnicki Józef Bronisław, [w:] Słownik biograficzny Wielkopolski południowo-wschodniej - ziemi kaliskiej, t. 2, red. D. Wańko, Kalisz 2003, s. 213.

35 Kalisz 1908, druk. K. W. Hindemitha.

36 Kalisz 1936 (Kalisz, Druk. J. Szczeciński).

${ }^{37}$ [Lisków], nakł. Oddziału Kat. Stow. Kobiet w Liskowie, 1938 (Kalisz, Antoni Krawczyk - Chrześc. Drukarnia Ziemi Kal.). 
Szesnaście lat później (1836) nakładem i drukiem Moritza (Maurycego) Schindele ukazała się 64-stronicowa dwujęzyczna Książeczka do sylabizowania i czytania, dla tych którzy po polsku i po niemiecku chcą uczyć się̨, w formacie $16,7 \times 10,3 \mathrm{~cm}$.

Cztery elementarze ukazały się w dwóch ostatnich dekadach XIX stulecia. W roku 1885 Oswald Arno Hindemith tłoczył własnym nakładem Elementarz niemiecki dla dzieci (16 s. , 16º). W tym samym roku z jego drukarni wyszedł Elementarz czyli początkowa nauka czytania. Swoim nakładem, pod tym samym tytułem, Hindemith ponownie drukował elementarz w roku 1895 i 1896, wydawnictwo o objętości 32 stron miało format $16 \times 10 \mathrm{~cm}$.

Ostatnim z siedmiu drukowanych w Kaliszu jest Elementarz polski ułożony podług metody pisania i czytania oparty na głosowaniu, z początku wieku XX (1906), wyszedł z drukarni "Gazety Kaliskiej” w formacie 19,5x14 cm i objętości 77 s.

\section{Podręczniki}

Obok elementarzy wydanych w wieku XIX, mamy też nieliczne przykłady podręczników z tego okresu. Karol Wilhelm Mehwald w roku 1810 tłoczył Grammatykę francuską dla pożytku uczącej się młodzieży krótko zebranąis, opatrzoną informacją „znacznie odmieniona, poprawiona i powiększona”. Czy Mehwald tłoczył wcześniejsze wydanie Grammatyki francuskiej..., trudno stwierdzić, nie odnotowano bowiem wcześniejszej edycji w spisie druków XIX i 1. połowy XX w., ani w Bibliografii starych druków kaliskich do końca XVIII w. Krystyny Bielskiej.

W roku 1887 ukazał się podręcznik geografii - Učebnik gieografii... - nauczyciela miejscowego Męskiego Gimnazjum Klasycznego Bronisława Gałczyńskiego, a wydał go księgarz Bronisław Szczepankiewicz ${ }^{40}$. Wymieniany już ks. Józef Bronisław Szafnicki, w roku 1899 pod kryptonimem J.B.S., nakładem i drukiem Ludwika Rosińskiego, wydał Historię Świętą i Historię Kościoła Katolickiego w krótkości dla młodzieży zebraną ${ }^{41}$.

Pierwsza połowa wieku XX przyniosła kilka podręczników z zakresu matematyki, geografii, gramatyki i historii.

Absolwent wydziału matematycznego i astronomicznego Uniwersytetu Charkowskiego Apolinary Klonowski (1849-1926)42, przez blisko 40 lat (do roku 1918) nauczyciel Miejskiego Gimnazjum Klasycznego w Kaliszu, jest także autorem wielu wydań podręczników arytmetyki, algebry, geometrii i astronomii, z których

38 Książeczka do sylabizowania i czytania, dla tych którzy po polsku i po niemiecku chcą uczyć się = Buchstaben uns Lesebuchlein für die, welche Polnisch und Deutsch lernen wollen, Kalisz, nakł. i druk Moritza Schindele, 1836.

39 Kalisz, druk K. W. Mehwalda, 1810.

40 Učebnik Gieografii, Azija, Afrika, Amerika i Awstralija w fizičeskom, polityčeskom i etnografičeskom otnošenijach: kurs Ilgo klassa, Kališ, izdanije knigoprodavca B. Ščepankieviča, 1887 (piečatno w tipografii A. Červinskago).

41 Kalisz, nakł. i drukiem L. Rosińskiego, 1899.

42 K. Walczak, Klonowski Apolinary, [w:] Słownik biograficzny Wielkopolski południowo-wschodniej..., t. 2, s. 102-103. 
część wydano w Kaliszu. W roku 1906 dwie części Zadań arytmetycznych ${ }^{43}$ tłoczyła Drukarnia „Gazety Kaliskiej”, a skład główny mieścił się w księgarni Bronisława Szczepankiewicza. W tym samym roku (1906) ukazały się w jednym tomie dwie części (5 i 6) Zadań algebraicznych, część piątą w roku 1908 drukował K. W. Hindemith w Kaliszu ${ }^{44}$. W latach 1907-1908 nakładem księgarni K. Idzikowskiego w Warszawie spod pras drukarni Hindemitha wyszły Zadania algebraiczne dla powtórzenia elementarnego kursu algebry (1907) oraz części 5 i 6 Zadań algebraicznych (1908) ${ }^{45}$. Część piątą Zadań algebraicznych wydał Klonowski nakładem własnym w roku 1916, a skład główny mieścił się u Perzyńskiego, Niklewicza i Spółki w Warszawie ${ }^{46}$.

W uznaniu zasług na polu geografii Polskie Towarzystwo Geograficzne w roku 1956 członkostwem honorowym obdarzyło Konstantego Bzowskiego, jednego z wybitniejszych metodyków geografii okresu międzywojennego. W latach 1903-1914 Bzowski pracował jako nauczyciel, kolejno w Szkole Handlowej w Kielcach (od 1903), w Męskim Gimnazjum w Łomży (1908-1910) i w Szkole Handlowej w Kaliszu (1910-1914). W latach 1915-1922 był dyrektorem kaliskiej Wyższej Szkoły Realnej typu matematyczno-przyrodniczego, później wizytatorem szkół średnich.

Bzowski był autorem blisko 80 opracowań, m.in. podręczników, artykułów i prac monograficznych z zakresu metodyki i dydaktyki geografii oraz propagatorem nowych metod pracy dydaktycznej. Niektóre podręczniki miały kilka wydań. W Kaliszu ukazały się cztery wydania Zarysu geologii i mineralogii dla uczniów klas starszych szkół średnich, wszystkie $(1914,1917,1918,1919)$ drukowane w Poznaniu w Drukarni „Dziennika Poznańskiego”. W edycji z roku 1914 i 1918 brak wydawcy, skład główny wydania drugiego (1917) posiadał M. Arct w Warszawie, który był wydawcą podręcznika w roku 1919 (wyd. 4) (7) $^{4}$ Wydanie drugie opatrzono informacją: Podręcznik zalecony przez Wydział Oświecenia; w części nakładu uwaga ta została zaklejona.

Cena podana w rublach (Rb. 1.30), markach (Mk. 2.80) i koronach (Kor. 3.30) w pierwszym wydaniu Zarysu geologii i mineralogii... świadczy, że książka miała być wykorzystywana na terenie wszystkich trzech dawnych zaborów.

Dwa wydania w Kaliszu miała Geografia Polski w dawnych granicach. Podręcznik szkolny dla młodzieży w wieku powyżej 15 lat K. Bzowskiego z mapą

${ }^{43}$ A. Klonowski, Zadania arytmetyczne. Cz. 2 (Ułamki), Kalisz 1906, druk „Gazety Kaliskiej” w Kaliszu; główny skład w księgarni B. Szczepankiewicza w Kaliszu; toż: Cz. 3. - 1906.

${ }^{44}$ A. Klonowski, Zadania algebraiczne, Cz. 5, 6, Kalisz 1906; tenże, Zadania algebraiczne, Cz. V, Kalisz 1908, druk K. W. Hindemitha.

${ }^{45}$ A. Klonowski, Zadania algiebraiczne dla powtórzenia elementarnego kursu algiebry, Kalisz, księg. K. Idzikowskiego w Warszawie, 1907, druk. K. W. Hindemitha; tenże, Zadania algebraiczne, Cz. V i VI, Kalisz, księg. K. Idzikowskiego w Warszawie, druk. K. W. Hindemitha, 1908, 8, cz. V, cz. VI.

${ }^{46}$ A. Klonowski, Zadania algebraiczne, Cz. 5, Kalisz, aut.; skł. gł. Perzyński, Niklewicz i Sp. Warszawa, 1916.

47 K. Bzowski, Zarys geologii i mineralogii dla uczniów klas starszych szkół średnich, Kalisz 1914, Druk. „Dziennik Poznański” Poznań; toż: wyd. 2. Kalisz, skł. gł. M. Arct, Warszawa, 1917, Druk. „Dziennik Poznański”, Poznań; toż: wyd. 3. Kalisz 1918 (Poznań, Druk. „Dziennik Poznański”); Kalisz, M. Arct, Warszawa, 1919 (Poznań, Druk. Tow. Akc. „Dziennika Poznańskiego”). 
Eugeniusza Romera. Wydanie pierwsze z 1918 r. tłoczyła drukarnia R. Kaniewskiego w Warszawie, wydanie drugie Drukarnia „Dziennika Poznańskiego ${ }^{48}$.

Najważniejsze wiadomości z gramatyki języka niemieckiego opracowane przez pedagoga, literata i tłumacza Zygmunta Reisa, germanistę w gimnazjum we Lwowie i Drohobyczu, wyszły w 1928 r. z kaliskiej Drukarni Wydawniczej. Jako miejsce wydania widnieje w publikacji Lwów, skład główny trzytysięcznego nakładu był natomiast w Domu Książki Polskiej w Warszawie ${ }^{49}$.

Broszurę na temat powstania styczniowego zatytułowaną Województwo kaliskie w walce 1863 i 186450, przeznaczoną dla młodzieży kaliskich szkół średnich, przygotował Józef Żmigrodzki, a tłoczyła go na prawach rękopisu Drukarnia Józefa (juniora) i Antoniego Radwanów.

\section{Samouczki}

Nakładem Maksymiliana Jasińskiego, prowadzącego działalność księgarską od roku 1917, ukazało się kilka druków z zakresu języka esperanto. W roku 1920 jako wydawnictwo Towarzystwa „Esperanto” w Kaliszu wyszedł samouczek języka międzynarodowego esperanto w dziesięciu lekcjach autorstwa Leopolda Kronenberga ${ }^{51}$.

Rok 1927 przyniósł dwie publikacje poświęcone esperantyzmowi wydane nakładem M. Jasińskiego i tłoczone w Drukarni Wydawniczej. W nakładzie 15 tysięcy egzemplarzy wyszło czwarte, przejrzane i uzupełnione wydanie Samouczka pomocniczego języka międzynarodowego Esperanto w dwunastu lekcjach metodą własną L. Kronenberga ${ }^{52}$.

Dnia 9 sierpnia 1926 r. w kaliskim ratuszu odbyło się zebranie organizacyjne Towarzystwa Esperantystów, wygłoszone wówczas wystąpienie opublikowane zostało jako słowo wstępne - „Esperanto zrzuca z ludzkości przekleństwo Babelu" - w wydanej w roku następnym pracy Antoniego Czubryńskiego pt. Esperantyzm. Książka informacyjna ${ }^{53}$, której wydanie pierwsze ukazało się w Krakowie w 1912 r. Książkę, której dwa rozdziały opracował Mieczysław Trochimowski, wydano w nakładzie 3000 egzemplarzy.

Trzy wydania w roku 1930 miał Kompletny samouczek języka Esperanto ze zbiorem wyrażeń handlowych i radiowych autorstwa Salomona Grenkamp-Kornfelda z przedmową prof. A. Cotton, członka Francuskiej Akademii Nauk ${ }^{54}$. Druk

48 K. Bzowski, Geografia Polski w dawnych granicach. Podręcznik szkolny dla młodzieży w wieku powyżej 15 lat, z mapą [Eugeniusza] Romera, Kalisz 1918 (Warszawa, Druk. R. Kaniewski); toż: wyd. 2. Kalisz 1919 (Druk. „Dziennik Poznański”).

49 Lwów, skład główny Dom Książki Polskiej w Warszawie, 1928 (Kalisz, Drukarnia Wydawnicza).

50 Kalisz, [b.w., 1936], Drukarnia J. i A. Radwanów.

51 L. Kronenberg, [Samouczek języka międzynarodowego esperanto w dziesięciu lekcjach], Kalisz, nakł. księgarni M. Jasińskiego, 1920. Wydawnictwo Tow. „Esperanto” w Kaliszu.

52 Wyd. 4, przejrzane i uzup., z portretem dra Zamenhofa, Kalisz, nakł. księgarni M. Jasińskiego w Kaliszu, 1927 (Kalisz, Drukarnia Wydawnicza).

53 Wyd. 2. Kalisz, nakł. M. Jasińskiego, 1927 (Kalisz, Drukarnia Wydawnicza).

54 Wyd. pierwsze. Jasło, Wydawnictwo - Eldonejo Esperantista Voco, 1930 (Kalisz, Drukarnia Wydawnicza); toż: wyd. 2. Jasło, Eldonejo, 1930 (Kalisz, Drukarnia Wydawnicza); toż: wyd. 3, Kalisz 1930. 
tłoczyła kaliska Drukarnia Wydawnicza dla wydawnictwa Eldonejo Esperantista Voco w Jaśle.

W roku 1929 dwa samouczki do nauki języka hiszpańskiego wyszły spod pras Drukarni Wydawniczej, oba w nakładzie po 2000 egzemplarzy ukazały się nakładem księgarni wydawniczej I. Igla we Lwowie. Oba samouczki: Rozmówki hiszpańsko-polskie z podaniem wymowy przy każdym słowie oraz Samouczek języka hiszpańskiego z rozmówkami opracował Jakub Reinhold ${ }^{55}$.

\section{Druki ciągłe (czasopisma, jednodniówki, kalendarze)}

\section{Czasopisma}

Pierwsze kaliskie czasopismo szkolne pojawiło się w roku 1904, było to tajne pismo uczniowskie pt. „Znicz” przy Gimnazjum Filologicznym (dziś I LO). Czasopisma wydawały szkoły powszechne i średnie, wychodziła prasa harcerska. Organem szkół powszechnych w roku 1920 było „Echo Szkolne”, na swych łamach zamieszczało także lekcje języka esperanto.

Krótko (1929-1930) wychodził dwutygodnik młodzieży szkół powszechnych redagowany najpierw przez uczniów i uczennice Powszechnej Szkoły im. Juliusza Słowackiego, a od numeru 3 - przez uczniów i uczennice powszechnych szkół w Kaliszu. Od numeru pierwszego w roku 1930 dołączyli uczniowie Szkoły Powszechnej w Liskowie.

Krótki był też żywot czasopisma pod tytułem „Echo Szkolne” wydawanego przez Koło Samokształcenia przy Gimnazjum im. A. Asnyka w Kaliszu; prawdopodobnie ukazały się trzy numery (R. 1, 1926, nr 1, 2; R. 2, 1926, nr 1). Od marca 1928 do 1931 r. ukazywała się „Pochodnia” - organ Kółka Literackiego przy Gimnazjum Państwowym im. A. Asnyka w Kaliszu, pismo wydawało „Koło Samokształceniowe" przy klasach VIII i VII tegoż gimnazjum. W latach 1931-1932 uczniowie klasy V Gimnazjum im. A. Asnyka wydali pięć numerów pisma pt. „Latawiec”.

Od września 1931 r. do października 1933 r. Koło Literacko-Naukowe „Kalina" przy Państwowym Gimnazjum Humanistycznym im. A. Asnyka (od 1932 Gimnazjum i Liceum im. A. Asnyka) wydawało pismo pt. „Sztubak”, na łamach którego debiutowali m.in. Edward Fiszer - autor tekstów popularnych piosenek i słuchowisk radiowych, Józef Garliński - pisarz emigracyjny, Stefan Otwinowski.

W latach 1924-1933 wychodziło także pismo młodzieży Gimnazjum Państwowego im. Tadeusza Kościuszki pt. „Świt”, którego wydawcą były kolejno: Miejscowy Związek Samopomocy Uczniów przy Gimnazjum Państw. im. T. Kościuszki, Związek Bratniej Pomocy, „Bratnia Pomoc” i „Gmina Szkolna” przy tymże gimnazjum. Od stycznia do marca 1927 r. młodzież „Kościuszki” wydawała na hektografie szkolne pisemko humorystyczne pt. „Blagier” („Blaga”).

55 J. Reinhold, Rozmówki hiszpańsko-polskie..., Lwów, nakł. księgarni wydawniczej L. Igla, 1929 (Kalisz, Drukarnia Wydawnicza); tenże, Samouczek języka hiszpańskiego..., Lwów, nakł. Księgarni wydawniczej L. Igla, 1929 (Kalisz, Drukarnia Wydawnicza). 
W grudniu 1933 r. staraniem Komitetów Redakcyjnych państwowych szkół średnich w Kaliszu nastąpiło połączenie „Świtu” ze „Sztubakiem” w jeden międzyszkolny miesięcznik pt. „Czyn i Słowo”. Czasopismo wydawał Międzyszkolny Komitet Redakcyjny złożony z przedstawicieli kaliskich szkół średnich; co roku siedzibę redakcji przenoszono do innej szkoły, zmieniał się także redaktor odpowiedzialny, którym był jeden z polonistów.

W roku 1929 r. wychodził „Głos Ucznia przy Gimnazjum Żydowskim w Kaliszu" - organ Bratniej Pomocy tego gimnazjum.

W latach 1933-1934 Zrzeszenie Patronatów Młodzieży w Kaliszu wydawało pismo pt. „Echo Kaliskich S.[towarzyszeń] M.[łodzieży] P.[olskiej]”, przez dwa lata (1935-1936) periodyk wychodził pt. „Echo Kaliskich K.S.M.” z podtytułem: Łącznik kaliskich placówek młodzieżowych, z kolei w latach 1937-1938 wyszły dwa roczniki pt. „Echo Katolickich Stowarzyszeń Młodzieży Okręgu Kaliskiego”.

Pierwszy numer miesięcznika Państwowego Seminarium Nauczycielskiego w Liskowie pt. „Ku Szczytom” (1924) odbito czcionkami Drukarni Ziemi Kaliskiej56.

Krótko (listopad 1915 - luty 1916) ukazywało się, pisane ręcznie i odbijane na hektografie, pisemko skautów pt. „Czuwaj”. W latach 1921-1939 wychodziły cztery czasopisma harcerskie. Od września 1921 r. ukazywał się „Wywiadowca” - pismo 3-ej Drużyny im. H. Sienkiewicza, wydawane przez Gimnazjum Miejskie Humanistyczne. Dwutygodnik ukazywał się jeszcze w roku 1922 (nr 1-5).

Komenda Hufca Kaliskiego w latach 1922-1923 była wydawcą pisma „Topograf". Inicjatorem wydawnictwa był druh Janusz Wize, jego śmierć w 1923 r. zakończyła wydawanie periodyku. Od maja 1924 r. do kwietnia 1926 r. wychodził miesięcznik młodzieży kaliskiej pt. „Głos Harcerza”, jego wydawcą była Komenda Hufca Żeńskiego i Męskiego. Przed wybuchem II wojny światowej ukazał się pierwszy numer biuletynu Obwodu Harcerstwa Kaliskiego pt. „Straż nad Prosną”, jego wydawcą był Wł. Chrzanowski.

\section{Jednodniówki}

Kilka wydarzeń upamiętnionych zostało wydanymi z tej okazji jednodniówkami. W roku 1932 ukazała się „Jednodniówka o Szkole Zawodowo-Dokształcającej w Kaliszu 1918-1932", jej redaktorem i wydawcą był Marian Tadeusz Janiak ${ }^{57}$, wcześniej redaktor pism kaliskich: „ABC Kaliskiego” w 1927 r., „Sztandaru Pracy” w 1928 r.

W roku 1937 „Jednodniówkę uczniów Szkoły Hodowlanej Łódzkiej Izby Rolniczej w Liskowie" 58 wydało Koło Koleżeńskie uczniów tej szkoły. Wydawnictwo dokumentujące kurs, który odbył się w czasie od 15 lipca do 15 grudnia 1937 r., tłoczyła drukarnia Józefa (juniora) i Antoniego Radwanów.

56 Lisków 1924 (Kalisz, Drukarnia Ziemi Kaliskiej); od nr. 2 zmiana tyt. na: „Liskowiak”.

57 Kalisz, [1932].

58 „Jednodniówka uczniów Szkoły Hodowlanej Łódzkiej Izby Rolniczej w Liskowie. Kurs od 15.VII-15.XII.1937 r." [Red. nacz. i odp.: Włodzimierz Dowgaj], Kalisz, Koło Koleżeńskie Uczniów Szkoły Hodowlanej Łódzkiej Izby Rolniczej w Liskowie, 1937 (Kalisz, druk Radwanów). 
Dwie jednodniówki wydało kaliskie Stowarzyszenie Młodzieży Polskiej. W roku 1926 z okazji pięciolecia działalności oraz uroczystości poświęcenia kamienia węgielnego pod gmach własny ukazała się jednodniówka pt. „Brzask”59, w roku 1934 natomiast „Jednodniówka Okręgu Kaliskiego Stowarzyszenia Młodzieży Polskiej z okazji 5-lecia istnienia 1929-1934"60.

W latach 1924-1937 wyszły trzy jednodniówki harcerskie, w tym dwie związane z jubileuszami działalności. Rocznicę dziesięciolecia istnienia Związku Harcerstwa Polskiego Hufiec Kaliski upamiętnił w roku 1924 wydaniem jednodniówki zatytułowanej „Zorza”61. Komitet Obchodu 25-lecia Harcerstwa Ziemi Kaliskiej w roku 1937 wydał jubileuszową jednodniówkę pt. „Straż nad Prosną 1912-1937”62. Zlot IV „Orlej” drużyny harcerskiej im. Księcia Józefa Poniatowskiego w Kaliszu w roku 1926 upamiętniła jednodniówka pt. „Zew Harcerza”63, wydana przez Komendę IV drużyny.

\section{Kalendarze}

Z kaliskich kalendarzy na uwagę zasługuje „Kalendarz na Szkołę Rzemiosł w Kaliszu", wydawany na lata 1907-191164. Z inicjatywą jego wydawania wystąpiła grupa kaliszan po zebraniu, na którym omawiano potrzebę utworzenia szkoły rzemiosł. Dochód ze sprzedaży wydawnictwa miał tworzyć kapitał przyszłej szkoły. Pięć edycji kalendarza tłoczyła drukarnia „Gazety Kaliskiej” Józefa Radwana, a na łamach gazety informowano o zainteresowaniu kalendarzem (np. M. Konopnicka przesłała wiersz do zamieszczenia w edycji na rok 1908), ukazywaniu się kolejnych roczników i ostatecznie o jego zawieszeniu. Na początku grudnia 1911 Komitet „Kalendarza na Szkołę Rzemiosł w Kaliszu”, dziękując za ofiarność i pomoc, informował, że wydawnictwo nie będzie się już ukazywać z przyczyn od Komitetu niezależnych ${ }^{65}$.

59 „Brzask. Jednodniówka Stowarzyszeń Młodzieży Polskiej w Kaliszu wydana z okazji pięcioletniego jubileuszu oraz uroczystości poświęcenia kamienia węgielnego pod gmach własny”, Kalisz, Stow. Młodz. Polskiej, [1926] (Kalisz, Zakłady Graficzne Teodor Żbikowski).

60 Kalisz, 1934 (Druk. Ziemi Kaliskiej).

61 „Zorza. Jednodniówka harcerska hufca kaliskiego. 1914-1924. Rocznica 10-ciolecia istnienia Z.H.P. w Kaliszu”, Kalisz, nakład K. H., 1924 (odbito czcionkami Drukarni Ziemi Kaliskiej).

62 „Straż nad Prosną 1912-1937. Jednodniówka jubileuszowa Harcerstwa Ziemi Kaliskiej”. Red. odp. Bronisław Chechłacz. Kalisz, wyd. Komitet Obchodu 25-lecia Harcerstwa Ziemi Kaliskiej, 1937 (Kalisz, druk Antoni Krawczyk - Chrześcijańska Drukarnia Ziemi Kaliskiej).

63 „Zew Harcerza. Jednodniówka zlotu IV-ej „Orlej” druż. harcerskiej im. Ks. Józefa Poniatowskiego w Kaliszu”. Red. odp.: Bronisław Niewiadomski. Kalisz, Komenda IV dr-ny im. Ks. J. Poniatowskiego w Kaliszu, 1926 (Druk, Zakłady Graficzne T. Żbikowski, Kalisz).

64 Kalisz 1907 (Kalisz, czcionkami i drukiem „Gazety Kaliskiej” pod zarządem Stanisława Rappaka); toż: „na rok przestępny 1908”, Kalisz 1908; toż: „na rok zwyczajny 1909”, Kalisz 1908; toż: „na rok zwyczajny 1910”, Kalisz 1909; toż: na rok zwyczajny 1911, Kalisz 1910.

65 F. Ł., „Kalendarz kaliski na szkołę rzemiosł”, „Gazeta Kaliska” 1906, nr 272, s. 2; „Gazeta Kaliska" 1907, nr 202, s. 2; 1911, nr 277, s. 4. 


\section{Oświatowe druki ulotne (popisy uczniów, ogłoszenia)}

Największą grupę druków oświatowych stanowią „popisy szkolne”, łłoczone przez oficynę Karola Wilhelma Mehwalda (1803-1824), powielane litograficznie przez S. Wildfeyera (1825), odbijane w drukarni Joanny Zuzanny Mehwald (1826-1828, 1830), w drukarni Józefa Poleskiego i komp. (1829), powielane litograficznie przez T. J. Jänischa (1834-1836, 1839-1841), tłoczone w drukarni Karola Wilhelma Hindemitha (1842-1844, 1846-1847)), w drukarni M. Schindele (1845). Programy „popisów” wychodziły dla Szkoły Akademickiej Okręgowej (1803-1804), a następnie kolejnych form tejże placówki w latach 1805-1852.

Pierwsze popisy wyszły pt. Uwiadomienie o popisach publicznych z nauk różnych w szkołach akademickich kaliskich dawanych (1803-1804)6 , w latach 1806-1810 w tytułach Uwiadomień... wprowadzono pewne zmiany. Od roku 1811 tytuł zmieniono na Popis(y) publiczne z języków i nauk uczniów Szkoły Departamentowej Kaliskiej..., choć tu także wprowadzano modyfikacje tytułu związane m.in. z nazwą szkoły. Tytuły zmieniały się również w kolejnych latach: Na akt (Akt) uroczysty Szkoły Obwodowej Kaliskiej..., Akt uroczysty zakończenia rocznego biegu nauk w Szkole Obwodowej Kaliskiej (...Szkole Powiatowej Kaliskiej..., ... Szkole Wyższej Realnej Kaliskiej...).

W historii miasta zapisał się w czasach Księstwa Warszawskiego, założony przez władze pruskie po III rozbiorze Polski, a przeorganizowany w 1808 r., Korpus Kadetów. Dwa razy do roku odbywały się tu egzaminy z przerobionego materiału. Uroczysty charakter popisów szkolnych miały egzaminy końcowe, a zapraszani goście otrzymywali program popisów z historią placówki, dziejami miasta, zmianami personalnymi w zespole nauczycielskim oraz ważniejszymi wydarzeniami w korpusie, które miały miejsce w minionym roku. W popisach wymieniano także nazwiska odznaczonych, wyróżnionych oraz promowanych kadetów. Egzaminy odbywały się pod koniec lipca i trwały od dwóch do czterech dni.

Pierwszy publiczny egzamin odbył się w roku $1809^{67}$, wówczas też wyszedł program pt. Na examen publiczny w Kaliskim Korpusie Kadetów dnia 26, 27, 28 i 29 Lipca Roku 1809 odprawić się mający, przyjaciół młodzieży pismem ninieyszem, w imieniu w-o pułkownika Podczaskiego, Kommendanta tego Korpusu, Krzyża Woyskowego Kawalera, zaprasza professor Frankowski, Przełożony nad Naukami w tymże Korpusie. W latach 1809-1915 program popisów ukazywał się niemalże pod takim samym tytułem, czasem dodawano informację dotyczącą, że jest to drugi (1810) czy szósty (1814) egzamin, zmiany dotyczyły też daty egzaminów.

Programy popisów liczyły od czterech (1809) do 28 (1815) stron, tylko pierwszy (1809) miał niewielki format $16^{\circ}$ (do $\left.20 \mathrm{~cm}\right)$, pozostałe wyszły w formacie $4^{\circ}$ (ponad $35 \mathrm{~cm}$ ). „Popisy” tłoczył Karol Wilhelm Mehwald (1809-1815).

66 W Kaliszu, 1803; toż: 1804.

67 J. Neuls-Korniszewska, Kaliskie szkoły średnie w latach 1793-1815, „Rocznik Kaliski” 1974, t. 7 , s. 67 . 
W roku 1817 wyszedł Program na popis publiczny uczniów Kaliskiego Korpusu Kadetów, w Bibliografii polskiej K. Estreichera odnotowano: „zapewne tożsamy z drukiem Na popis publiczny uczniów kaliskiego korpusu kadetów. Ukazały się także programy „popisów” na rok 1818 i 1819, oba pod tytułem Na popis publiczny uczniów Szkoły rycerskiej w Kaliszu mający się odbywać w dniach...

W Kaliszu drukowane były też programy „popisów” uczniów Szkoły Obwodowej w Sieradzu i Wieluniu. Wszystkie „popisy” Szkoły Obwodowej w Sieradzu wyszły w dużym formacie (ponad $35 \mathrm{~cm}$ ), pierwszy w 1834 pt. Na popis uczniów szkoły obwodowej w Sieradzu... ${ }^{68}$, kolejne, w latach 1835-1840, pt. Akt uroczysty zakończenia rocznego biegu nauk w Szkole Obwodowej Sieradzkiej... ${ }^{69}$, drukowane w litografii T. J. Jenisza.

Także „popisy” dla Szkoły Obwodowej Wieluńskiej (1834-1841) drukowane były w litografii T. J. Jenisza w dużym formacie. Program na rok 1834 wyszedł pt. Na akt uroczystości kończącego się roku szkol. Szkoły Obwodowej Wieluńskiej, zaprasza Mar[cin] Wysznacki Insp. ${ }^{70}$, kolejne, w latach 1835-1841 pt. Na akt uroczysty mający zakończyć rok Szkolny w Szkole Obwodowey Wieluńskiéy... ${ }^{71}$.

W listopadzie 1860 roku zmarł Edward Ślósarski - uczeń klasy piątej Szkoły Wyższej Realnej w Kaliszu, mowa żałobna, którą wygłosił ks. Józef August Herbich, nauczyciel religii w tejże szkole, wygłoszona na nabożeństwie w intencji zmarłego, opublikowana została w roku następnym ${ }^{72}$.

Przykład pomocy uczniom poza budynkiem szkolnym stanowi ogłoszenie o odczycie nauczyciela Bronisława Gałczyńskiego popularyzującym nauki przyrodnicze ${ }^{73}$.

Na uwagę zasługują także oświatowe druki ulotne z 1905 r.; pismo o wybuchu strajku szkolnego w Kaliszu i Łowiczu („W Kaliszu, dnia 31 stycznia rozpoczął się powszechny strajk robotniczy...”, nie wcześniej niż 3 lutego 1905), pisma ulotne z żądaniami uczniów kaliskich szkół średnich: męskiego gimnazjum filologicznego (7 lutego 1905), gimnazjum żeńskiego (8 lutego 1905) i gimnazjum realnego (9 lutego 1905), odezwa Tymczasowego KC Kaliskiej Młodzieży Szkolnej

68 Na popis uczniów szkoły obwodowej w Sieradzu 28 i 29 Lipca 1834 zaprasza inspektor [Adam] Bartoszewicz, Kalisz, 1834.

69 Akt urocz. zakończenia rocznego biegu nauk w S. obw. Sieradzkiej. [Kalisz? 1835]; Akt uroczysty Zakończenia Rocznego Biegu Nauk w Szkole Obwodowej Sieradzkiej odbyć się mający dnia 30 Lipca na który Szanowną Publiczność Inspektor Szkoły wraz ze Zgromadzeniem Nauczycielskim zaprasza. Kalisz, T. J. Jenisz litogr., 1836; toż: Kalisz 1838; toż: 1839; toż: Kalisz 1839 [właśc. 1840].

70 Wieluń; Kalisz, T. J. Jänisch, litogr., 1834.

71 Na akt uroczysty mający zakończyć rok Szkolny w Szkole Obwodowey Wieluńskiéy który się odbędzie w Gmachu Szkolnym dnia 30-go lipca 1835 roku od godziny 9-téy rano Prześwietną Publiczność Imieniem Instytutu zaprasza Marcin Wysznacki Inspektor Szkoły, Wieluń; [Kalisz, T. J. Jänisch, litogr.?], 1835.

72 J. A. Herbich, Mowa na żałobném nabożeństwie za pokój duszy ś. p. Edwarda Ślósarskiego Ucznia Klassy Véj Szkoły Wyższej Realnéj w Kaliszu, zmarłego dnia 21 Listopada 1860 roku, miana dnia 24 Listopada t. r. w Kościele ś. Mikołaja, Kalisz, druk. W. Hindemitha, 1861.

73 [Ogłoszenie] [Inc.:] W niedzielę dnia 8(20) Grudnia 1874 roku w miejscowym teatrze Bronisław Gałczyński magister nauk przyrodzonych na korzyść Progimnazjum Kaliskiego będzie miał odczyt pod tytułem: Rzut oka na świat zwierzęcy i roślinny w pasie zwrotnikowym [...], Kalisz, 1874 (druk. J. Mroczka), 1 k. - Tekst również w jęz. ros. 
wzywająca do strajku szkolnego („Towarzysze i towarzyszki! W końcu nadszedł dzień, kiedy my, młodzież szkolna...”, Kalisz 23 lutego 1905), drukowana hektograficznie oraz ustawa Kaliskiego Towarzystwa Oświatowego (Kalisz 1905, 8 s. ).

\section{Stan zachowania egzemplarzy - próba oceny}

\section{Biblioteki Kalisza}

Pośród omówionych wyżej druków oświatowych ani w zbiorach kaliskich bibliotek, ani innych bibliotek na terenie kraju nie zachował się ich komplet. Z siedmiu wydanych w Kaliszu elementarzy żadnego nie ma w miejscowych książnicach, brak też edycji podręczników K. Bzowskiego Zarys geologii i mineralogii dla uczniów klas starszych szkół średnich oraz Geografii Polski w dawnych granicach (1919). Z wydawanych w latach 1803-1852 „popisów szkolnych” część znana jest tylko z Bibliografii polskiej Karola Estreichera.

Druki oświatowe znaleźć można w zbiorach Książnicy Pedagogicznej im. A. Parczewskiego (8 edycji), Miejskiej Biblioteki Publicznej im. A. Asnyka (13 edycji), biblioteki Muzeum Okręgowego Ziemi Kaliskiej (7 edycji, 2 czasopisma) i Kaliskiego Towarzystwa Przyjaciół Nauk, choć w ostatniej z wymienionych instytucji jest to tylko jeden druk - jednodniówka „Brzask”. Podkreślić trzeba, że tytuły (poza jednym przypadkiem) nie powtarzają się.

Książnica Pedagogiczna posiada Ustawę Szkoły Handlowej siedmioklasowej w Kaliszu (1904), pracę Pauliny Rościszewskiej Kilka słów do mojego syna (1857), dalej Witolda Grabowskiego Wspomnienia Kaliszanina o życiu młodzieży akademickiej w latach 1884-1888 (1932), „Jednodniówkę o Szkole Zawodowo-Dokształcającej w Kaliszu 1918-1932” (1932), „Jednodniówkę uczniów Szkoły Hodowlanej Łódzkiej Izby Rolniczej w Liskowie” (1937), edycje „Kalendarza na Szkołę Rzemiosł w Kaliszu” (1907, 1908, 1910). Poza tym wiele kaliskich wydawnictw oświatowych w bibliotece pedagogicznej dostępnych jest w postaci mikrofilmów, m.in. szereg „popisów szkolnych”.

\section{Informacje o egzemplarzach w innych zbiorach}

Wiele tytułów kaliskich druków spotkać można w zbiorach kilkunastu największych bibliotek na terenie kraju, przede wszystkim w Bibliotece Narodowej i Bibliotece Uniwersyteckiej w Warszawie. W narodowej książnicy, obok kilkunastu tytułów, jest niedostępne gdzie indziej czasopismo „Głos Ucznia przy Gimnazjum Żydowskim w Kaliszu” (1929), w Bibliotece Uniwersyteckiej z kolei m.in. Instytut edukacyjny... Karola Herzberga (1808), edycje elementarzy, czasopisma szkolne i programy „popisów szkolnych”. Biblioteka Jagiellońska w Krakowie posiada 
m.in. wydania podręczników geografii K. Bzowskiego. Kilka edycji znaleźć można w zbiorach Biblioteki Głównej Uniwersytetu Adama Mickiewicza w Poznaniu.

Pojedyncze tytuły kaliskich druków oświatowych posiadają: biblioteka Zakładu Narodowego im. Ossolińskich, Biblioteka Śląska w Katowicach, Wojewódzka Biblioteka Publiczna - Książnica Kopernikańska w Toruniu, Biblioteka Główna Uniwersytetu Mikołaja Kopernika w Toruniu, Wojewódzka i Miejska Biblioteka Publiczna w Łodzi, Pedagogiczna Biblioteka Wojewódzka w Łodzi. Egzemplarz najstarszej edycji elementarza z 1820 r. znajduje się w zbiorach Biblioteki Poznańskiego Towarzystwa Przyjaciół Nauk.

Bibliografia "Druki kaliskie XIX i pierwszej połowy XX w. (1800-1945)” rejestruje 1623 tytuły, z czego ok. 12\% to wydawnictwa oświatowe. W kaliskiej produkcji wydawniczej i drukarskiej mamy zarówno przykłady oświatowych aktów prawnych, druków tłoczonych na rzecz szkolnictwa wyższego, prac związanych $z$ doskonaleniem zawodowym i kwestiami wychowania. Miejscowe drukarnie tłoczyły elementarze i podręczniki, także o zasięgu ogólnopolskim oraz samouczki, poza tym publikacje poświęcone dziejom miejscowego szkolnictwa. Wychodziła prasa szkolna i harcerska oraz jednodniówki i „popisy”. Jednak największą grupę - 66 edycji - stanowią charakterystyczne dla szkoły dziewiętnastowiecznej „popisy", czyli programy uroczystych egzaminów końcowych wydawane w pierwszej połowie XIX w. dla szkół kaliskich oraz szkoły w Wieluniu i Sieradzu. W wieku XIX ukazało się sześć edycji elementarzy oraz interesujące wydawnictwa dotyczące wychowania.

Wiek XX z kolei przyniósł podręczniki arytmetyki i algebry Apolinarego Klonowskiego oraz geografii Konstantego Bzowskiego, pisma uczniowskie i harcerskie. W okresie międzywojennym warto zwrócić uwagę na interesujące samouczki języka esperanto, mające z pewnością wymiar nie tylko lokalny.

Tłoczone w Kaliszu druki oświatowe to w większości edycje lokalne. Ale są też przykłady książek drukowanych dla wydawców Iwowskich (Politechnika, księgarnia wydawnicza Leiba Igla), warszawskich czy łódzkich. 